\title{
Justification of environmental safety criteria in the context of sustainable development of the construction sector
}

\author{
Elena Smirnova ${ }^{1 *}$ and Arkadij Larionov ${ }^{2}$ \\ ${ }^{1}$ Saint Petersburg State University of Architecture and Civil Engineering, Vtoraja Krasnoarmejskaja \\ ul. 4, 190005, St. Petersburg, Russia
}

${ }^{2}$ National Research University - Moscow State University of Civil Engineering, 26, Yaroslavskoye shosse, 129337, Moscow, Russia

\begin{abstract}
In the article the authors attempt to determine environmental safety criteria in the field of construction activities. A comprehensive methodological rationale for environmental safety in the construction industry is given. The system of environmental monitoring, the criteria and conditions for its implementation, as well as the principles of environmental monitoring set out in environmentally friendly standards, are considered. Analysis of the environmental monitoring system at all stages of the construction products life cycle showed that departmental confusion impedes the development of environmentally oriented investment and construction activities. Under these conditions, it is necessary to create an independent structure focused on environmental protection. The transfer of maximum powers to it will make it possible to quickly solve the problems of environmental monitoring as part of the movement towards sustainable and balanced development of the country.
\end{abstract}

\section{Introduction}

The vivid direct impacts (harmful emissions, waste generation, etc.) and indirect effects (influence on individual's health, aggravation of quality of environment, etc.) will be assessed at all stages of the construction produce life cycle. Presently, a significance of indirect results of construction influence on the environment grows, especially over the long term [1]. Whereas, the investment and construction activity has an effect on the quality of environment, the authors see an efficient mean of environmental management in the system of ecological monitoring: it is connected to systematization and analysis of information on the state of environment; on the reasons of observed and probable changes of its quality; on admissibility of changes and loads on the environment as a whole; on the existing reserves of eco-systems.

The authors suppose that a sustainable development encompasses the equilibrium economical, technological and social state of certain territories with preservation of viable

\footnotetext{
* Corresponding author: esmirnovaee@ mail.ru
} 
habitat in the country. It should be noted that the solution of this task will be attained in the process of creative, rather than the destructive interaction of the community and nature with a focus on the fact that the application of architectural and civil engineering solutions and construction technologies not satisfying specific features of the territories should be restricted. Otherwise, it will bring about the drastic alterations of the landscapes, violation of stability of the ecological and economical structure. In other words, the destruction of environment will result in the loss of the structural standard properties and functions of the territory. A transformation of natural resource potential and a replacement of natural landscapes with anthropogenic ones will take place. In this respect the system of ecological monitoring contemplates implementation of the following tasks: assess indicators of state and functional integrity of eco-systems and human habitat; reveal the reasons of changing these indicators; predict consequences resulting from such changes; define corrective measures in those cases, when the target indicators of ecological conditions are not attained; consider prerequisites to determine measures for correcting the resultant negative situations before any damage is inflicted. The goal is the same indeed: creation of positive environment for vital life sustenance of people and business, which could become a basis for supporting health and working ability of the general public, balanced economical development of the state as a whole [3]. In connection with the foregoing the authors face the following tasks: give consideration to an integrated methodological substantiation for providing ecological safety in the construction sphere, investigate an issue on the criteria of ecological safety due to sustainable development of the construction sphere and the eco-economic equilibrium as a whole, analyze the system of ecological monitoring, criteria and conditions for its implementation.

\subsection{Background}

The ecological optimization approach is typical of many scientific studies and searching the ways of safe development of the territories [e.g. 4-14]. However, hardly anybody of the authors addresses the issues of the criteria of environmental safety in connection with the sustainable development of construction sphere. On the contrary, an issue of eco-economic equilibrium until now evokes fierce debates and remains to be one of the most challenging [e.g. 15-18]. D.L. Meadows, J. Randers, D., W. Behrens, D.H. Meadows, B. Commoner, M. Mesarovic and Y. Takahara et alia have made the greatest contribution into development and implementation of this problem [19-23]. The works of V.I. Vernadsky, N.F. Rejmers, V.I. Telichenko, M.Y Slesarev, A.N. Tetior and many others can be distinguished among Russian scholars [24-27].

\section{Materials and Methods}

The analysis of criteria of environmental safety in connection with the sustainable development of the construction sphere is based on the experience of identification of the system-level eco-economic processes (it is a case of the method of ecological balance). The authors adhere in their scientific rationale to the well-proven dynamic model of Meadows group. Its subject matter consists in that the mankind has already exceeded the limits of selfrenewal of the Earth's eco-systems. The favorable scenarios of eco-economic equilibrium have become unattainable along with the material growth of the population endowment. The consumption of natural resources and destruction of the environment result in the more and more unpredictable way in an extremely unfavorable (basic) scenario. The time for implementation of favorable scenarios has been irretrievably lost [20-21]. Meadows emphasizes that the disastrous changes will become inevitable without a significant correction of natural resources consumption by the mankind in the nearest time. D. Meadows 
[19] assumes 5 basic indicators of the stability model: 1) accelerating industrialization, 2) growth of population endowment, 3) threat of food deficit, 4) depletion of resources, 5) deterioration of environment quality.

The principles of environmental safety and stability unveiled in the book of B. Commoner [22] come forward as one of the most significant indicators for this analysis. Let us briefly review these in the context of forecasting the innovative ecologically-safe technologies. The scholar underlines that the least change in nature introduced from outside may entail the avalanche-type destruction of natural systems. For instance, it is a real ecological disaster what has happened to the Aral Sea. The excessive withdrawal of water for irrigation of the cultivated land has turned the world's fourth-biggest sea-lake, rich animate nature earlier, into an arid desert. B. Commoner also dwells on the law of redistribution and circulation of elements. It should constitute a closed circle in the eco-system (producers, decomposers, consumers). However, the people have synthesized hazardous chemicals that have never existed in nature (dichloro-diphenyl-trichloroethane, polypropylene, polyethylene, etc.). These compounds do not enter a natural process of redistribution. The man-induced systems have thrown people into a problem of waste disposal. This is why the subject of waste-free production, greening the industry and agriculture is so challenging. The following principle is reckoned by $\mathrm{B}$. Commoner to be fundamental for the sustainable development: the nature is perfect. It is necessary to exercise an extreme care in the actions for environment transformation; any unnatural changes in the eco-system will inevitably bring about the irreversible alterations. It will be necessary to pay in one way or other for the development that does not meet the goals of environmental safety. Anything new necessarily expels the old in the eco-system. It is just the price paid for evolution by the nature. Though, the human activity disturbs a natural course of events introducing corrections unusual for the eco-system therein. B. Commoner refers to these as the "bill" payments. So, the application of GM food (GMO) has resulted in that we pay by our health for the consumption thereof. Moreover, the self-amplifying process of destruction of the natural organisms is complemented with degradation of the immediate environment for human life and activities.

A model of sustainable development created by N.F. Rejmers is also significant for the authors in methodological respect. It is targeted to scientific substantiation of nature protection and provision of environmental safety in the production-induced zones. The environment protection and environmental safety cost cutting results for the people in the considerable health impairment, negative anthropogenic processes and decline of favorable conditions for life. If the socio-economic adaptation has followed the environmental changes earlier, now it should precede these, since the nature, including a human-being as a biological subject have no more safety margin left [25]. It is also important to take into account a fundamental significance of the second biogeochemical law of V.I. Vernadsky [24] saying that the migration of chemical elements takes place in biosphere with the mandatory direct or indirect participation of the living organisms. Any losses in the content of the living matter will trigger an avalanche destruction of the entire biogeochemical system. The quality of construction directly depends on correct setting and solution of ecological tasks and permanent assessment of environmental impacts at all stages of the project life cycle. The intensity and versatility of these impacts have already exceeded in many respects the rate of adaptation and stability of natural systems. Let us repeat once again: a natural resource potential shall not be lower than the level of resources withdrawal and rate of changing the people's living environment. It is worthwhile speaking in the context of the environment protection problem of the investment potential of ecological construction, which facilities should be regarded as the investment produce with the characteristic features [28]. The authors think that the complex of the foregoing innovative principles helps assess a state of environmental safety of engineering solutions, variants of territories development, investment and construction activity for the sake of minimization of man-induced impacts on 
the eco-systems, timely reveal any potentials of dangerous development and make forecasts of the optimal variants of stability [29].

\section{Results}

The principles and methods of environment monitoring are described in the ecologically oriented standards. ISO 14000 is one of these standards. According to this standard the construction enterprise should develop its ecological policy as well as carry out the documented procedures of monitoring and measurement based on characteristics of production processes, and ecological aspects thereof. It considers the influence of processes of extraction of raw materials, fabrication of construction materials, construction proper and demolition, burial of construction waste or recycling on the environment [30-31].

In order to overcome the drawbacks of traditional construction, a number of "green" standards has been developed too on the basis of principles of sustainable development and providing for safe and favorable conditions for the people' vital life sustenance, acceptable level of impact on the environment and taking into account a wide range of interests: BREEAM (Building Research Establishment Environmental Assessment Method), developed by BRE Global company; - LEED (The Leadership in Energy \& Environmental Design) offered by the U.S. Green Building Council (USGBC); - DGNB (Deutsche Gesellschaft für Nachhaltiges Bauen) presented for supporting the "green" building by the Council of sustainable construction of Germany. All of them contribute to expanding the spheres of business, hi-tech production, innovations and information telecommunication technologies, improve the state of the environment. So, the mandatory requirements of LEED system are aimed at the construction of eco-friendly, economically- and energy-efficient buildings and entire districts convenient for living with the use of biopositive architectural and planning design concepts (see Table 1) [32].

Table 1. Mandatory requirements of LEED system.

\begin{tabular}{|c|c|c|}
\hline $\begin{array}{l}\text { Line } \\
\text { No. }\end{array}$ & LEED requirement & Explanation \\
\hline 1 & $\begin{array}{l}\text { Reduced pollution by } \\
\text { construction activity }\end{array}$ & $\begin{array}{l}\text { It will be implemented at the early stages of construction. It is } \\
\text { practically impossible to receive a certificate for certificates } \\
\text { initially not planned for LEED }\end{array}$ \\
\hline 2 & $\begin{array}{l}\text { Reduced water } \\
\text { consumption }\end{array}$ & $\begin{array}{l}\text { The criterion sets rigid requirements regarding the use of } \\
\text { energy-saving sanitary ware }\end{array}$ \\
\hline 3 & $\begin{array}{l}\text { Putting into operation } \\
\text { the energy-saving } \\
\text { systems in the } \\
\text { building }\end{array}$ & $\begin{array}{l}\text { It will be implemented at the early stages of designing. It is } \\
\text { practically impossible to receive a certificate for certificates } \\
\text { initially not planned for LEED }\end{array}$ \\
\hline 4 & $\begin{array}{l}\text { Minimum } \\
\text { requirements to } \\
\text { energy-efficiency }\end{array}$ & $\begin{array}{l}\text { The criterion contemplates compliance with the requirements } \\
\text { of American standard of energy-efficiency of buildings } \\
\text { (ASHRAE) comprising tight standards with respect to } \\
\text { equipment in HVAC systems, heat conductivity of the } \\
\text { enclosing structures, air tightness of building and systems }\end{array}$ \\
\hline 5 & $\begin{array}{l}\text { Air conditioning } \\
\text { management }\end{array}$ & $\begin{array}{l}\text { The criterion produces requirements regarding the use of } \\
\text { freon-containing refrigerants }\end{array}$ \\
\hline 6 & $\begin{array}{l}\text { Collection and storage } \\
\text { of the secondary } \\
\text { resources }\end{array}$ & $\begin{array}{l}\text { The criterion dictates organization of separate collection of } \\
\text { waste, providing a site for storage of recyclable materials }\end{array}$ \\
\hline 7 & $\begin{array}{l}\text { Quality of } \\
\text { microclimate }\end{array}$ & $\begin{array}{l}\text { The criterion standardizes the levels of air exchange in the } \\
\text { building }\end{array}$ \\
\hline
\end{tabular}


DGNB takes into account the entire life cycle of the building and gives evaluation in accordance with more than 50 criteria grouped into six categories: quality of environment, economic efficiency, sociocultural qualities and functionality, technical equipment, process quality, location quality. The strategy of increasing capital expenses with the aim of minimizing the operational expenses over a long period is well-disposed for the investorsdevelopers planning to operate the real property. This approach assumes consideration of full life cycle of the building, evaluation of investments into green construction and payback thereof within an operational period. The "green" construction is connected with the synergetic effect, which proves itself, when ecological, economical, technological and other effects complement and amplify each other creating a general effect exceeding the effects of every factor involved into economical process time and time again quantitatively and qualitatively. The biopositive construction projects generate conditions for equilibrium and steady relationship between eco-system and economics of construction under conditions of changing environment and internal transformations [33].

A loss of stability may happen for the following reasons: changed system parameters (bifurcation); availability of external impacts; disturbance of communication (structure) in the system. Let us consider, what are the basic criteria of ecological monitoring with the aim of precluding the irreversible natural processes from the positions of such negative determination of stability. Let us enumerate these criteria: continuity over time, indefiniteness over a distance, adequacy of information for providing accuracy of evaluation, smart-response; necessary authorities for taking decisions. The continuity of evaluation guarantees that the environmental situation is under control. The functioning of monitoring system is required for the purposes of testing the state of environment connected with the construction facility: revealing facility under control over time and its location, borders, illbeing external manifestations; thereafter, primary facility investigation in the form of random short-time observation over it with clarification of pollution indicators; determination of points or zones of further investigation from the positions of integrity of biotope territory and environmental safety of construction impact on the biotic community; establishment of the information model of facility under control over a long period with the integrated forecast of possible negative impact of construction activities on the environment (in the face of aggravation of situation and before emergence of unamendable consequences); planning of experiment (as a result of timely response) for studying the state and dynamics of the facility being controlled in order to collect data on possible deviations from the normal value and provide for due ecological monitoring of the environment, its protection against anthropogenic impact of construction. Thus, the durable (systematic) observations of the facility and evaluation of its state as a whole, forecasting changes of its quality on the basis of information model (GIS) with the use of methods of stochastic approximation and recursive estimation, approbation of experimentally acquired empirical data depending on the supposed changes of external conditions, processing and providing the fullest scope of information on open access and bringing it to the consumer's knowledge by means of innovative methods and scientific investigations - all these constitute a system of estimation of environmental safety [34].

\section{Discussion}

The respective authorities of organizational structure dealing with the system of ecological monitoring could be attributed to implementation of full closed cycle of facility estimation from carrying out expert evaluation to suspension of construction due to violation of laws, regulations, rules, instructions, disregard of obligations connected with protection of the environment, deliberate violation of ecological legislation and management of natural resources, abuse of authorities, etc. Presently, multiple agencies and subordinate 
organizations deal with the functions of control of environment state, abidance by the laws, etc. (Table 2).

Table 2. Departmental distribution of functions in the framework of the Unified state system of ecological monitoring (USSEM).

\begin{tabular}{|c|c|}
\hline Federal authority & Functions \\
\hline $\begin{array}{l}\text { Ministry of Natural } \\
\text { Resources and } \\
\text { Environment of the } \\
\text { Russian Federation }\end{array}$ & $\begin{array}{l}\text { Coordination of activity of the Ministries and departments, enterprises } \\
\text { and organizations in the field of environmental monitoring, organization } \\
\text { of monitoring of impact on the environment and the areas of direct } \\
\text { impact thereof, organization of monitoring of animal and vegetal life, } \\
\text { monitoring of terrestrial fauna and flora (except forests), provision of } \\
\text { establishing and functioning of ecological information systems, } \\
\text { maintenance of databanks on the environment, natural resources and the } \\
\text { use thereof with the Ministries and departments concerned }\end{array}$ \\
\hline $\begin{array}{l}\text { Federal Service for } \\
\text { Hydrometeorology and } \\
\text { Environmental } \\
\text { Monitoring }\end{array}$ & $\begin{array}{l}\text { Organization of monitoring of the state of atmosphere, land headwaters, } \\
\text { marine environments, soils, near-Earth space environment, integrated } \\
\text { background and space monitoring of the state of environment, } \\
\text { coordination of development and functioning of departmental } \\
\text { subsystems of background monitoring of the environment, keeping a } \\
\text { state data fund on environmental pollution }\end{array}$ \\
\hline $\begin{array}{l}\text { Federal Subsoil } \\
\text { Resources Management } \\
\text { Agency }\end{array}$ & $\begin{array}{l}\text { Monitoring of subsoil resources (geological environment), including } \\
\text { monitoring of subsoil waters and dangerous exogenous and } \\
\text { endogenous geological processes }\end{array}$ \\
\hline $\begin{array}{l}\text { Federal Forestry } \\
\text { Agency }\end{array}$ & Monitoring of forests \\
\hline $\begin{array}{l}\text { Federal Agency for } \\
\text { Water Resources }\end{array}$ & $\begin{array}{l}\text { Monitoring of aquatic environment of water utilization systems and } \\
\text { structures at water withdrawal points and points of discharge of sewage } \\
\text { waters }\end{array}$ \\
\hline $\begin{array}{l}\text { Federal Geodesy and } \\
\text { Cartography Agency }\end{array}$ & $\begin{array}{l}\text { Exercising topographic-geodesic and cartographic support of USSEM, } \\
\text { including creation of digital and electronic maps and geographic } \\
\text { information systems }\end{array}$ \\
\hline $\begin{array}{l}\text { State Technical } \\
\text { Oversight Authority }\end{array}$ & $\begin{array}{l}\text { Coordination of development and functioning of subsystems of } \\
\text { monitoring of geological environment connected with the use of } \\
\text { subsoil resources at the extractive industry companies, monitoring of } \\
\text { providing industrial safety (except facilities of the Ministry of Defense } \\
\text { of the Russian Federation) }\end{array}$ \\
\hline $\begin{array}{l}\text { Ministry of Defense of } \\
\text { the Russian Federation }\end{array}$ & $\begin{array}{l}\text { Monitoring of environment and sources of impact thereupon at the } \\
\text { military facilities, provision of USSEM with the devices and systems } \\
\text { of double-use military equipment }\end{array}$ \\
\hline $\begin{array}{l}\text { Ministry of Agriculture } \\
\text { of the Russian } \\
\text { Federation }\end{array}$ & $\begin{array}{l}\text { Provision of establishment and functioning of the departmental system } \\
\text { of environment monitoring. }\end{array}$ \\
\hline 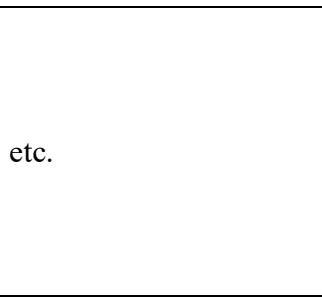 & $\begin{array}{l}\text { Transfer of maximum authorities to an independent structure focused } \\
\text { on the environment protection promptly solving the emerging problems } \\
\text { remains to be a relevant objective for implementation of the most } \\
\text { important ecological requirement - bring the rate of ecosystems } \\
\text { service into equilibrium with the intensity of self-recovery thereof. The } \\
\text { natural resource potential should be equal to or exceed the level of } \\
\text { resources withdrawal and rate of changing the life sustenance } \\
\text { environment. }\end{array}$ \\
\hline
\end{tabular}

The arising ecological infringements are most frequently connected to the sphere of construction activity and require an immediate response. However, due to a departmental mess it is impossible in every particular case to provide protection of the environment in full. Though, the functioning of ecological monitoring system contemplates an efficient management of the system of estimation, continuity of control, authenticity of information, 
promptness of response to possible deviations from regulations. However, this unified approach to the development and carrying out the programs of observation of the state of environment becomes impossible due to a fact that every department and subdepartment work in their informational fields possessing limited authorities only. According to N.F. Rejmers all spheres of the community's vital activities should be subordinated to the requirements of ecological policy under conditions of the existing ecological tension. The science, politics and ideology should become in this case a unified tool for cultivating philosophy of ecological stage of society development [25]. In this context it is necessary to establish a strategic independent (non-departmental) control authority endowing it with powers in implementing a unified scientific and technical policy in the field of ecological monitoring. The activity of this institution will be related to: coordination of development and carrying out the programs of observations of the state of environment; regulatory activity and control of collection and processing true data; storage of information, keeping special data banks and coordination thereof with the international environment information systems; activity for estimating and forecasting the state of environment objects, natural resources, reaction of eco-systems and the people's health to an anthropogenic impact; availability of the integrated ecological information to a wide range of customers.

It is necessary not only to make the departmental control of carrying out measures for environment protection tougher (which is logical of its own accord to maintain ecological equilibrium), but to channel significant capital investments for preserving all surviving elements of the eco-system. The amount of about $160 \mathrm{bln}$. US dollars will become the socially warrantable expenses for saving it by 2025 . Given that species disappear out of existence at the rate of 1 specie a day, it turns out that even now the world expenses required for saving the species equal approximately $30 \mathrm{bln}$. US dollars annually [25]. A determination of volume of necessary capital investments that could be channeled by business including investors of the construction sphere for saving the eco-system of Russia remains to be a relevant task for future investigations.

\section{Conclusions}

Finally, the scientific fundamentals of the nature-protection monitoring consist in the prompt provision of the environmental safety system with the up-to-date and true information, making it possible to structure the observation, diagnostics and warning with due account of the latest technologies and the holistic vision of the surrounding world. An anthropogenic load on the environment continues to grow in Russia despite a declared ecological efficiency; it does not meet the objectives of sustainable development under conditions of the growing rate of demand for the raw materials. The desertification, deforestation increase, the problems of urban smog, climate change, depletion of ozone layer, biological resources, etc. have not been solved. The urbanized territories exist under continuing external human impact on the eco-system, which gets intensively deteriorated. The general condition of such territories is critical, and sometimes it is disastrous. An absence of ecological reserve for equilibrium and sustainable development of the country has become a response of the eco-systems to unpractical nature management and anthropogenic pressure. The construction sphere greening proceeds slowly in our country. The departmental mess, low culture of management, technocratic thinking obstructs the practical solution of many ecological issues. This analysis of criteria of environmental safety in the context of sustainable development of the construction sphere has demonstrated that it is necessary to establish an independent structure focused on the environmental protection. A transfer of maximum powers to this structure will help promptly solve ecological problems, in the construction industry, in particular. 


\section{References}

1. Larionov, E. Nezhnikova, ARPN J. of Eng. and Appl. Sc. 11(3), 2023-2029 (2016).

2. E. Smirnova, Ohrana okruzhajushhej sredy i osnovy prirodopol'zovanija [Environmental protection and environmental management] (SPbGASU, Saint Peterburg, 2012).

3. E. Smirnova, V. Zaikin, E3S Web of Conf. 91, Article 05030, 1-12 (2019). https://doi.org/10.1051/e3sconf /2019910

4. Sorensen, J. Okata, (eds.) Megacities: Urban Form, Governance, and Sustainability (Springer, Tokyo, 2011). https://doi.org/10.1007/978-4-431-99267-7

5. K. Ahmed, M. Shahbaz, A. Qasim, W. Long, Ec. Ind. 49, 95-103 (2015). https://doi.org/10.1016/j.ecolind.2014.09.040

6. S. Polasky, C. Kling, S. Levin, S. Carpenter, G. Daily ... J. Lubchenco, PNAS 116(12), 5233-5238 (2019). https://doi.org/10.1073/pnas.1901616116

7. J.S. Shapiro, \& R. Walker, Am. Ec. Rev. 108(12):3814-54 (2018).

8. S.T. Pickett, M.L. Cadenasso, D.L. Childers, M.J. Mcdonnell \& W. Zhou, J. Ecosys. Health and Sustain. 2(7), Article e01229 (2017). https://doi.org/10.1002/ehs2.1229

9. P. Esposito, F. Patriarca, L. Perini, L. Salvati, Environ. Dev. Sustain. 18(2), 431-448 (2016). https://doi.org/10.1007/s10668-015-9655-9

10. T. McPhearson, S. Pickett, N. Grimm, J. Niemelä, M. Alberti ... S. Qureshi, BioSc. 66(3), 198-212 (2016). https://doi.org/10.1093/biosci/biw002

11. P.K. Narayan; B. Saboori; A. Soleymani, Ec. Modell. 53, 388-397 (2016). https://doi.org/10.1016/j.econmod.2015.10.027

12. R.J. Standish, R.J. Hobbs, J.R. Miller, Landscape Ecolog. 28(6), 1213-1221 (2013). https://doi.org/10.1007/s10980-012-9752-1

13. T. Baynes, T. Wiedmann, Cur. Opin. in Environ. Sustain. 4, 1-7 (2012). https://doi.org/10.1016/j.cosust.2012.09.003

14. M.N. Echenique, A.J. Hargreaves, G. Mitchell, A. Namdeo, J. Am. Plann. Assoc. 78(2), 121-137 (2012). https://doi.org/10.1080/01944363.2012.666731

15. K.S. Schmitz, Ecology. In Physical Chemistry: Multidisciplinary Applications in Society (pp. 833-974) (Elsevier, Amsterdam, 2018). https://doi.org/10.1016/B978-0-12800513-2.00005-X

16. R. Proctor, Sustainable Design Book (Laurence King Publishing Ltd, London, 2015).

17. Sayigh, Sustainability, Energy and Architecture: Case Studies in Realizing Green Buildings (Elsevier, Amsterdam, 2014).

18. R. Heinberg, The End of Growth: Adapting to Our New Economic Reality (New Society Publishers Gabriola Island, BC, 2011).

19. D.H. Meadows; D.L. Meadows; J. Randers, W. Behrens, The Limits to Growth: A Report for the Club of Rome's Project on the Predicament of Mankind (Universe Books, New York, 1982).

20. D.H. Meadows, D.L. Meadows, J. Randers, Beyond the Limits: Global Collapse or a Sustainable Future (Earthscan, London, 1995).

21. D. Meadows, J. Randers, D. Meadows, Limits to Growth. The 30-Year Update (Earthscan, London, 2005).

22. B. Commoner, The Closing Circle: Nature, Man, and Technology (Knopf, New York, 1971). 
23. M.D. Mesarovic \& Y. Takahara, General Systems Theory: Mathematical Foundations (Academic Press, New York, 1975).

24. V.I. Vernadsky, Biosphere and Noosphere (Airis-Press, Moscow, 2012).

25. N.F. Rejmers, Nadezhdy na vyzhivanie chelovechestva. Konceptual'naja jekologija [Hopes for the survival of mankind. Conceptual ecology] (Rossija molodaja, Moscow, 1992).

26. M.Y Slesarev, V.I. Telichenko, IOP Conf. Ser.: Mater. Sc. and Eng. 456, Article 012126 (2018).

27. A.N. Tetior, Jekositi: Problemy, Reshenija [Ecocity: problems, solutions] (NIA-Priroda, Moscow, 2005).

28. Larionov, E. Nezhnikova, Intern. J. of Appl. Eng. Resear. 11(6), 4433-4439 (2016).

29. E. Smirnova, V. Gorohov, Monitoring i obrashhenie s othodami v megapolisah [Monitoring and waste management in megacities] (SPbGASU, Saint Peterburg, 2019).

30. R. Hillary (ed.), ISO 14001: Case studies and practical experiences (Routledge, London, 2017).

31. A.C. Affam, E.H. Ezechi, Handbook of Research on Resource Management for Pollution and Waste Treatment (IGI Global, Hershey, 2019). DOI: 10.4018/978-1-79980369-0

32. S. Zhukovsky, A. Surkov, A. Kychkin, Vestnik PNIPU. Prikladnaja jekologija. Urbanistika [PNRPU Bul. Urb. Dev.] 11, 80-92 (2017). https://doi.org/10.15593/24095125/2017.01.07

33. E. Smirnova, Espacios 39(22) (2018).

https://www.revistaespacios.com/a18v39n22/18392240

34. M. Slesarev, V. Telichenko, D. Nguyen, MATEC Web of Conf. 251, Article 02010 (2018). https://doi.org/10.1051/matecconf/201825102010 